\title{
Evaluating the safety of $\beta$-interferons in MS
}

\author{
A series of nested case-control studies \\ OPEN
}

Hilda J.I. de Jong, PhD Elaine Kingwell, $\mathrm{PhD}$ Afsaneh Shirani, MD Jan Willem Cohen

Tervaert, $\mathrm{PhD}, \mathrm{MD}$

Raymond Hupperts, $\mathrm{PhD}, \mathrm{MD}$

Yinshan Zhao, PhD

Feng Zhu, MSc

Charity Evans, PhD

Mia L. van der Kop, MSc

Anthony Traboulsee, MD

Paul Gustafson, $\mathrm{PhD}$

John Petkau, PhD

Ruth Ann Marrie, PhD, MD

Helen Tremlett, PhD

On behalf of the British

Columbia Multiple

Sclerosis Clinic

Neurologists

Correspondence to

Dr. Tremlett:

helen.tremlett@ubc.ca

Supplemental data at Neurology.org

\section{ABSTRACT}

Objective: To examine the association between interferon- $\beta$ (IFN- $\beta$ ) and potential adverse events using population-based health administrative data in British Columbia, Canada.

Methods: Patients with relapsing-remitting multiple sclerosis (RRMS) who were registered at a British Columbia Multiple Sclerosis Clinic (1995-2004) were eligible for inclusion and were followed up until death, absence from British Columbia, exposure to a non-IFN- $\beta$ diseasemodifying drug, or December 31, 2008. Incidence rates were estimated for each potential adverse event (selected a priori and defined with ICD-9/10 diagnosis codes from physician and hospital claims). A nested case-control study was conducted to assess the odds of previous IFN- $\beta$ exposure for each potential adverse event with at least 30 cases. Cases were matched by age ( \pm 5 years), sex, and year of cohort entry, with up to 20 randomly selected (by incidence density sampling) controls. Odds ratios (ORs) with 95\% confidence intervals (95\% Cls) were estimated with conditional logistic regression adjusted for age at cohort entry.

Results: Of the 2,485 eligible patients, $77.9 \%$ were women, and 1,031 were treated with IFN- $\beta$ during follow-up. From the incidence analyses, 27 of the 47 potential adverse events had at least 30 cases. Patients with incident stroke $\left(\mathrm{OR}_{\mathrm{adj}} 1.83,95 \% \mathrm{Cl} 1.16-2.89\right)$, migraine $\left(\mathrm{OR}_{\mathrm{adj}} 1.55\right.$, $95 \% \mathrm{Cl} 1.18-2.04)$, depression $\left(\mathrm{OR}_{\text {adj }} 1.33,95 \% \mathrm{Cl} 1.13-1.56\right)$, and hematologic abnormalities $\left(\mathrm{OR}_{\text {adj }} 1.32,95 \% \mathrm{Cl} 1.01-1.72\right)$ were more likely to have previous exposure to IFN- $\beta$ than controls.

Conclusions: Among patients with RRMS, IFN- $\beta$ was associated with a 1.8- and 1.6-fold increase in the risk of stroke and migraine and 1.3-fold increases in depression and hematologic abnormalities. Neurology ${ }^{\circledR}$ 2017;88:2310-2320

\section{GLOSSARY}

BC = British Columbia; $\mathbf{B C M S}=$ British Columbia Multiple Sclerosis; $\mathbf{C l}=$ confidence interval; $\mathbf{D M D}=$ disease-modifying drug; ICD-9/10 = International Classification of Diseases, ninth/10th revision; INF- $\boldsymbol{\beta}=$ interferon- $\boldsymbol{\beta}$; $\mathbf{M S}=$ multiple sclerosis; $\mathbf{O R}$ = odds ratio; $\mathbf{R R M S ~}=$ relapsing-remitting multiple sclerosis.

Multiple sclerosis (MS) is a chronic inflammatory demyelinating and degenerative disease of the CNS causing pronounced neurologic disability. MS affects $\approx 2.3$ million individuals worldwide $^{1} ; \approx 85 \%$ are initially diagnosed with relapsing-remitting MS (RRMS), characterized by clearly defined exacerbations and periods of disease stability after recovery. Several pharmacologic treatments have been developed for RRMS, including the first-line therapy interferon- $\beta$ (IFN- $\beta$ ). The IFN- $\beta$ s are modestly effective, reducing relapse rates by about one-third and having a beneficial effect on imaging outcomes, ${ }^{2}$ but findings regarding longer-term effects on disability have been mixed. ${ }^{3,4}$ The IFN- $\beta$ s are generally considered safe, especially compared to

From the Division of Neurology and Centre for Brain Health (H.J.I.d.J., E.K., A.S., Y.Z., F.Z., M.L.v.d.K., A.T., H.T.), Department of Medicine, and Vancouver Coastal Health Research Institute, University of British Columbia, Canada; School for Mental Health and Neuroscience (H.J.I.d.J., J.W.C.T., R.H.), Maastricht University Medical Center, the Netherlands; College of Pharmacy and Nutrition (C.E.), University of Saskatchewan, Saskatoon, Canada; Department Public Health Sciences (M.L.v.d.K.), Karolinska Institutet, Stockholm, Sweden; Department of Statistics (P.G., J.P.), University of British Columbia, Vancouver, Canada; and Departments of Internal Medicine and Community Health Sciences (R.A.M.), Max Rady College of Medicine, Rady Faculty of Health Sciences, University of Manitoba, Winnipeg, Canada.

Coinvestigators are listed at Neurology.org.

Go to Neurology.org for full disclosures. Funding information and disclosures deemed relevant by the authors, if any, are provided at the end of the article. The Article Processing Charge was funded by the Canadian Institutes of Health Research and National Multiple Sclerosis Society.

This is an open access article distributed under the terms of the Creative Commons Attribution-NonCommercial-NoDerivatives License 4.0 (CC BY-NC-ND), which permits downloading and sharing the work provided it is properly cited. The work cannot be changed in any way or used commercially without permission from the journal. 


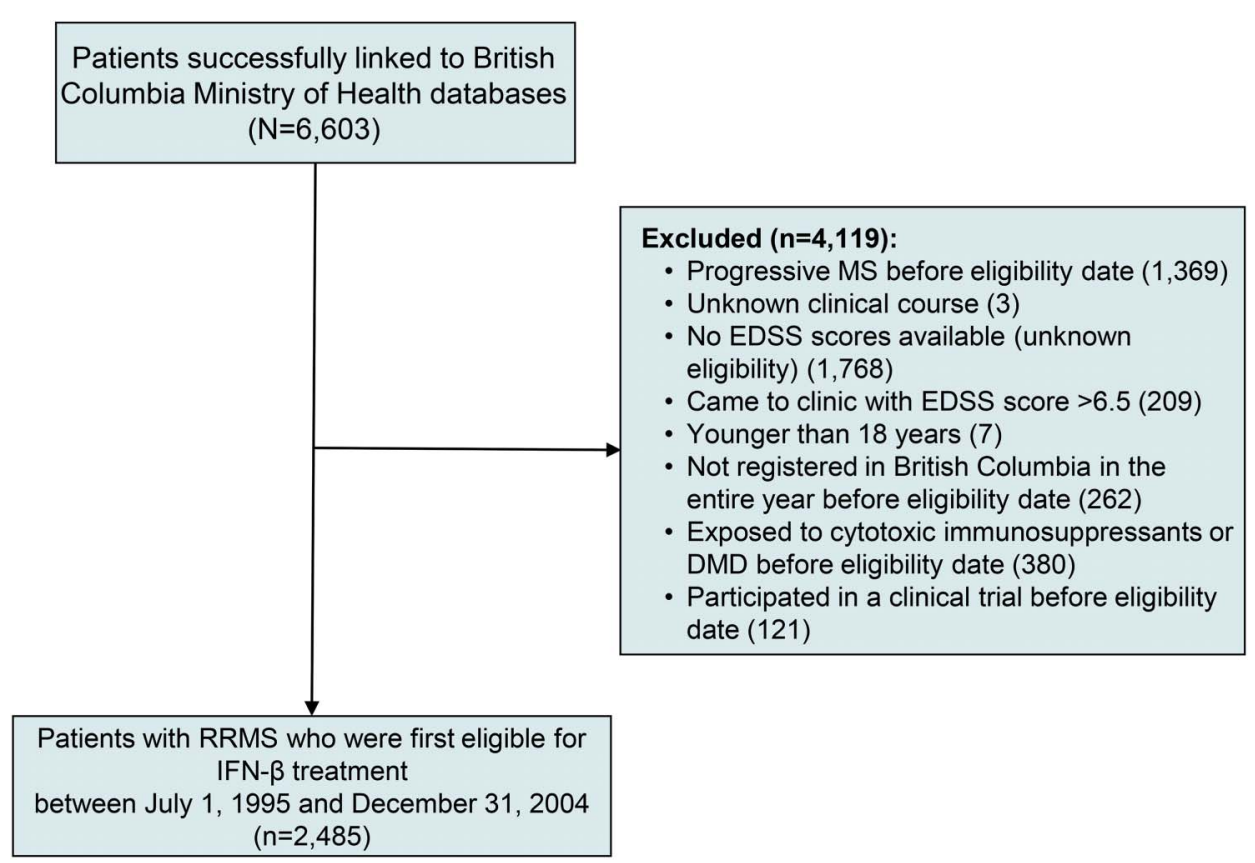

DMD = disease-modifying drugs; EDSS = Expanded Disability Status Scale; IFN- $\beta=$ interferon- $\beta$; MS = multiple sclerosis; RRMS = relapsing-remitting multiple sclerosis.

newer agents for MS. ${ }^{5}$ However, few studies have systematically assessed their safety in real-world clinical practice (appendix e-1 at Neurology.org). 5 A meta-analysis of 9 clinical trials estimated that patients treated with IFN- $\beta$ had a 2.8 -fold increased risk of discontinuing drug because of an adverse event compared to the placebo group. The most common adverse events were flu-like symptoms, injection-site reactions, leukopenia, lymphopenia, and elevated liver enzymes. ${ }^{6}$ However, because of their short duration and relatively small sample sizes, clinical trials cannot identify all potential adverse effects of a drug treatment or predict the safety of the drug in clinical practice. Furthermore, participants in clinical trials are highly selected in terms of comorbidities and concomitant medications and often differ substantially from patients who use the drug once it reaches the market. We identified signals of potential adverse events related to IFN- $\beta$ treatment in a large population-based cohort of patients with RRMS.

METHODS Data source and setting. This study used prospectively collected clinical data and population-based administrative health data from the province of British Columbia (BC),
Canada. MS-specific clinical data were obtained from the British Columbia Multiple Sclerosis (BCMS) database, ${ }^{4}$ which contains information onwards patients who first attended 1 of the $4 \mathrm{MS}$ clinics in BC (1980 on). We accessed a cohort of BCMS patients whose clinical data were previously linked to $\mathrm{BC}$ administrative data and stripped of personal identifiers (data spanned 19802008; linkage and deidentification were completed in 2010). ${ }^{4}$ Data linkage was performed at the individual level with the use of personal health numbers (a unique lifelong identifier). Once linked, it is not permissible to reidentify an individual patient. The linked administrative data included PharmaNet (filled drug prescriptions), ${ }^{7}$ Medical Service Plan Payment information (physician visit dates with diagnoses coded using the ICD-9/10), ${ }^{8}$ the Discharge Abstract Database (hospital discharge diagnoses, coded as ICD-9/10), ${ }^{9}$ Census Geodata (aggregated data on neighborhood socioeconomic status), ${ }^{10}$ Vital Statistics (death dates) ${ }^{11}$ and the BC Registration and Premium Billing File (registration status in the mandatory provincial health care plan, enabling confirmation of residency in $\mathrm{BC}$, as well as age and sex). ${ }^{12}$

Standard protocol approvals, registrations, and patient consents. The Clinical Research Ethics Board of the University of British Columbia approved the study, which included patient consent.

Study population. All patients with definite RRMS according to the Poser or McDonald criteria who were eligible for IFN- $\beta$ treatment and first registered at a BCMS clinic between July 1 , 1995, and December 31, 2004, were selected. Eligibility criteria for IFN- $\beta$ treatment (first licensed in Canada in 1995) were broadly adapted from the BC government's reimbursement scheme and were defined as age $\geq 18$ years, definite relapsingonset course, and ability to walk (Expanded Disability Status Scale score $\leq 6.5$ ). Because of the reimbursement requirements and availability of the MS specialist neurologists in BC, $>99 \%$ of patients receiving IFN- $\beta$ before 2005 would have been assessed at 
a BCMS clinic and captured in the database. ${ }^{13}$ The cohort entry date was defined as the first recorded BCMS clinic date at which eligibility criteria were met for each individual. Before cohort entry, all patients had to be resident in BC and free of the study outcome of interest for at least the previous year and not enrolled in an MS clinical trial or exposed to another disease-modifying drug (DMD). All patients were followed up until the study outcome, death, absence from $\mathrm{BC}$ ( $>3$ consecutive months), exposure to non-IFN- $\beta$ DMDs, or December 31, 2008 (study end date), whichever came first.

Identifying the study outcomes. The incident outcomes (i.e., potential adverse events) were selected after a comprehensive literature search, including product monographs (appendix e-1). ${ }^{14-16}$ Incident cases of the potential adverse events arising during the study period were identified with the use of ICD-9/ 10 diagnostic codes from physician and hospital visits (appendix e-2). The ICD-9/10 codes for adverse drug events were not used because they are nonspecific and likely underrepresent the number of adverse drug events.

Analytic approach and defining the exposure. We used a 2step approach, including an incidence analysis to estimate the incidence of the potential adverse events in the linked cohort followed by a series of nested case-control studies, one for each selected potential adverse event. This approach provides an efficient study design and has been shown to yield virtually identical findings as a Cox regression model using the full cohort $^{17}$ and therefore should not affect findings. We estimated the incidence rates by dividing the number of incident cases by the total number of person-years of follow-up, expressed per 1,000 person-years. Based on the incidence rates, potential adverse events were selected, regardless of exposure to IFN $-\beta$, for further study (table e-1).

Drug exposure information (i.e., start and stop dates) was obtained primarily from PharmaNet, supplemented by the BCMS database (for data such as participation in clinical trials). For the nested case-control models, exposure to IFN- $\beta$ before the first identification of the potential adverse event, i.e., the index date, was described as ever exposed ( $\geq 1$ dispensations of IFN- $\beta$ vs no record of exposure before the index date). In addition, the cumulative duration (days) of IFN- $\beta$ treatment was categorized as none, $>0$ to $\leq 2$ years, or $>2$ years. Recentness of use was defined as current use (IFN- $\beta$ exposure within 3 months before the index date) or past use ( $>3$ months before the index date); these were each compared with nonuse ( 0 days).

Nested case-control sampling. To avoid underpowered comparisons, only potential adverse events for which at least 30 incident cases were observed in the incidence analyses were selected for further analysis. For each case, we randomly selected up to 20 controls matched by age ( \pm 5 years), sex, and cohort entry year and randomly selected from the population of patients at risk for the condition of interest at the case's index date (i.e., by incidence density sampling). This method ensures that cases and controls have comparable follow-up duration.

We assessed the effect of potential confounders beyond the matching factors on the associations between each adverse event and IFN- $\beta$ treatment (ever, cumulative duration, and recentness of use). Potential confounders were included in the final model if they independently changed the estimated effect for IFN- $\beta$ exposure by $\geq 10 \% .{ }^{18}$ Potential confounders, as measured at cohort entry, included MS-related clinical characteristics (disease duration, and Expanded Disability Status Scale score [disability level] categorized as $\leq 4$ or $>4$ ) and socioeconomic status expressed as quintiles of average neighborhood relative to regional income and

\section{Table 1 Characteristics of the MS study population at cohort entry (eligibility date)}

\begin{tabular}{|c|c|}
\hline Characteristics & $\begin{array}{l}\text { Study population } \\
\text { ( } \mathrm{n}=2,485)\end{array}$ \\
\hline Female sex, n (\%) & $1,936(77.9)$ \\
\hline \multicolumn{2}{|l|}{ Age at cohort entry } \\
\hline Mean (SD), y & $41.3(10.0)$ \\
\hline $18-30$ y, n (\%) & 326 (13.1) \\
\hline $31-40$ y, n (\%) & 832 (33.5) \\
\hline $41-50$ y, n (\%) & 851 (34.2) \\
\hline$>50$ y, n (\%) & 476 (19.2) \\
\hline $\begin{array}{l}\text { Age at MS onset, mean (SD) } \\
(\mathrm{n}=2,478), y\end{array}$ & $31.8(9.2)$ \\
\hline \multicolumn{2}{|l|}{ Disease duration $(n=2,478)^{a}, y$} \\
\hline Mean (SD) & $9.5(8.7)$ \\
\hline Median (IQR) & $7.0(2.3-14.5)$ \\
\hline EDSS score, median (IQR) & $2.0(1.5-3.0)$ \\
\hline \multicolumn{2}{|l|}{$\begin{array}{l}\text { Neighborhood income } \\
\text { quintile, } \mathrm{n}(\%)\end{array}$} \\
\hline 1 (Lowest) & $342(13.8)$ \\
\hline 2 & $398(16.0)$ \\
\hline 3 & 465 (18.7) \\
\hline 4 & 459 (18.5) \\
\hline 5 (Highest) & $343(13.8)$ \\
\hline Missing & 478 (19.2) \\
\hline \multicolumn{2}{|l|}{$\begin{array}{l}\text { Comorbidity in the previous } \\
\text { year, } \mathrm{n}(\%)\end{array}$} \\
\hline Heart disease & $64(2.6)$ \\
\hline Epilepsy & $40(1.6)$ \\
\hline Depression & $416(16.7)$ \\
\hline Liver disease & $13(0.5)$ \\
\hline Renal disease & $9(0.4)$ \\
\hline Thyroid abnormalities & $8(0.3)$ \\
\hline Hematologic abnormalities & 41 (1.7) \\
\hline
\end{tabular}

Abbreviations: EDSS $=$ Expanded Disability Status Scale; $\mathrm{IQR}=$ interquartile range; MS = multiple sclerosis.

By virtue of the study design, which included selection of new (incident) users of interferon- $\beta$ (IFN- $\beta$ ) based on their first known eligibility date for drug and exclusion of prior use of other disease-modifying drugs (DMDs), no individuals were known to have been exposed to IFN- $\beta$ or any other DMDs for MS before cohort entry.

${ }^{a}$ Disease duration was defined as time from MS symptom onset to cohort entry; MS onset date was unavailable for 7 patients.

generated from Statistics Canada's Postal Code Conversion File using income data from the Canadian population. ${ }^{10}$ Other potential confounders considered were the prebaseline comorbidities (defined as one relevant ICD code in the year before cohort entry date) with which IFN- $\beta$ should be used with caution (i.e., depression, epilepsy, hematologic abnormalities, or renal, liver, thyroid, or heart diseases). ${ }^{14-16}$ To minimize the risk of residual confounding by age, all models were adjusted for age in years (as 
Table 2 Characteristics of the cases and controls for each potential adverse event with ORs and 95\% Cls for IFN- $\beta$ exposure

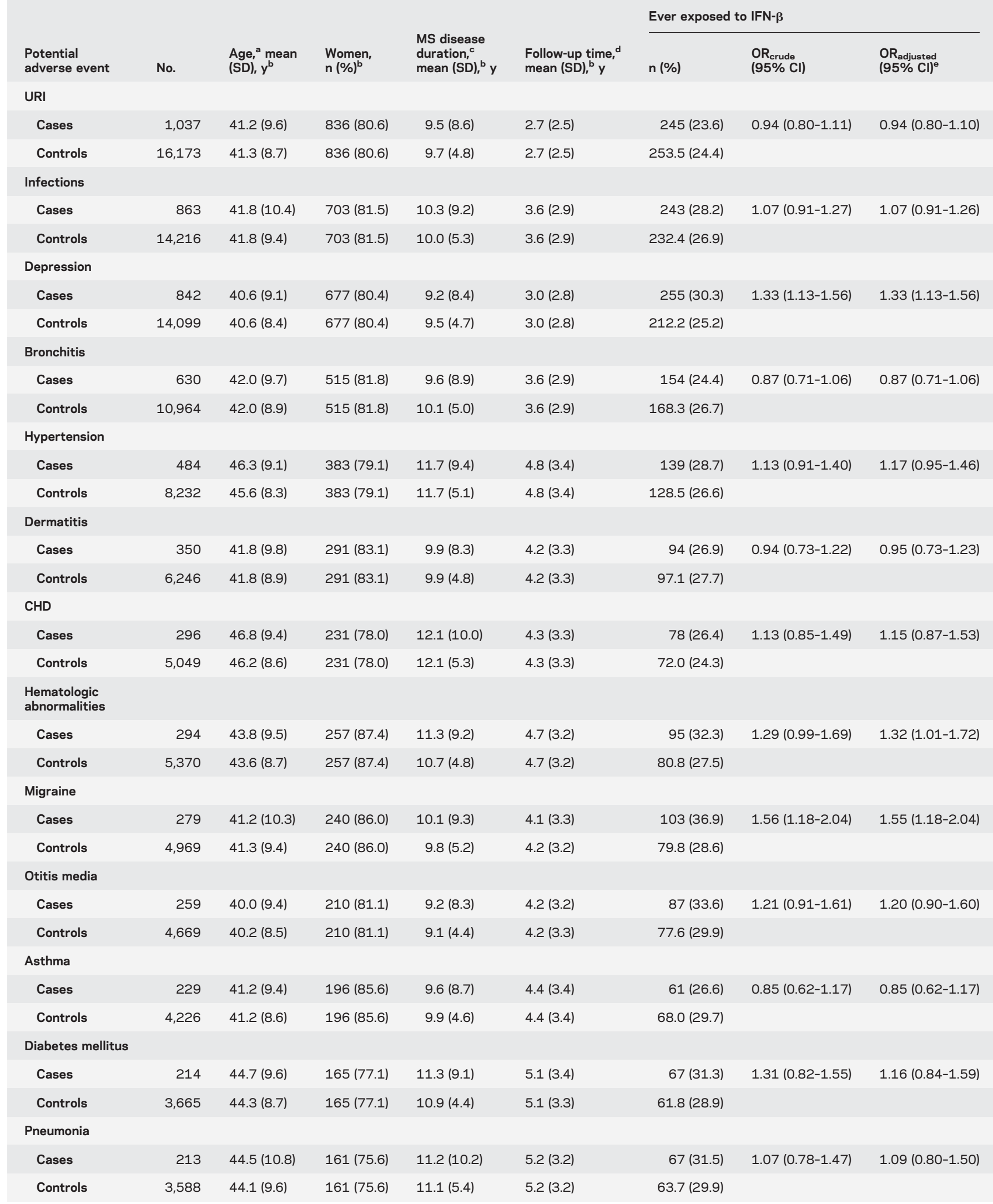

Continued 


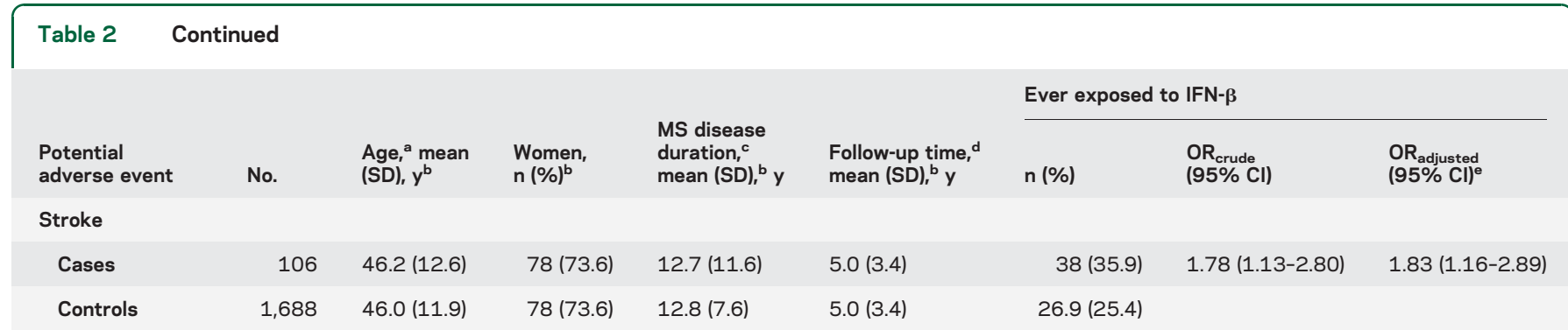

Abbreviations: $\mathrm{CHD}=$ coronary heart disease; $\mathrm{Cl}=$ confidence interval; IFN- $\beta=$ interferon- $\beta$; $\mathrm{MS}=$ multiple sclerosis; OR $=$ odds ratio; URI $=$ upper respiratory infections.

"Ever exposed" indicates that at least one prescription for an IFN- $\beta$ was dispensed (filled) before the index date.

${ }^{\text {a }}$ At cohort entry date.

${ }^{\mathrm{b}}$ To account for any variation in the number of controls per case between risk sets, all means \pm SDs, proportions, and percentages reported for controls were weighted by the inverse number of controls in each set.

${ }^{\mathrm{c}} \mathrm{MS}$ disease duration: the years from MS onset to the date of eligibility for IFN- $\beta$ treatment (cohort entry).

${ }^{d}$ Follow-up time: the years from cohort entry to the date of the event in the case and equivalent date in the controls (index date).

${ }^{e}$ Adjusted for age (in years) at the cohort entry date; no other covariates were included in the final models because none were associated with case/control status.

a continuous variable); this complemented the matching of cases and controls by age ( \pm 5 years).

We assessed the association between IFN- $\beta$ exposure and potential adverse events using multivariable conditional logistic regression, with findings reported as odds ratios (ORs) with 95\% confidence intervals (CIs). For this exploratory study, we purposely avoided any specific a priori hypotheses and did not adjust for multiple comparisons.

Analyses were performed with SAS, version 9.3 (SAS Institute Inc, Cary, NC).

RESULTS From the linked cohort of 6,603 patients with MS, 2,485 patients with RRMS were eligible for inclusion (figure). Among these patients, 1,770 were followed up until the study end date, 380 were followed up to the initiation of an immunosuppressant for treatment of MS or a non-IFN- $\beta$ DMD (78\% of whom started with glatiramer acetate), 103 died, and 232 left the province. At the cohort entry date, the mean age of the 2,485 patients was 41.3 (SD 10.0) years, and $77.9 \%$ were women (table 1). During a mean follow-up of 8.0 (SD 3.8) years, 1,031 $(41.5 \%)$ were treated with an IFN- $\beta$.

Incidence analysis. From the incidence analyses, 27 of the 47 of the examined clinical conditions (potential adverse events) were identified with at least 30 cases regardless of treatment exposure (table e-1).

Nested case-control analyses. Each of the 27 clinical conditions were studied in separate nested casecontrol analyses (tables 2-4 and tables e-2-e-4). Cases and controls were similar for the matching variables of age, sex, and follow-up time to the adverse event (table 2). Average MS disease duration differed by a maximum of 1.7 years between cases and controls. Patients with at least one hospital or physician claim for stroke $\left(\mathrm{OR}_{\mathrm{adj}} 1.83,95 \% \mathrm{CI}\right.$ 1.16-2.89), migraine $\left(\mathrm{OR}_{\text {adj }} 1.55\right.$, 95\% CI 1.182.04), depression $\left(\mathrm{OR}_{\mathrm{adj}} 1.33,95 \% \mathrm{CI} 1.13-1.56\right)$, or hematologic abnormalities $\left(\mathrm{OR}_{\mathrm{adj}} 1.32,95 \% \mathrm{CI}\right.$ $1.01-1.72)$ were more likely to have previous exposure to IFN- $\beta$ than their matched controls. For all other potential adverse events, no notable differences in ever vs never exposure to IFN- $\beta$ were observed (table 2).

The baseline characteristics for the cases and controls in the nested case-control studies of stroke, migraine, depression, and hematologic abnormalities are summarized in table e-5. Comorbidities were generally distributed similarly between these cases and their controls.

The associations between cumulative duration and recentness of IFN- $\beta$ treatment and most common potential adverse event are reported in tables 3 and 4. The odds of stroke, migraine, and hematologic abnormalities within the exposure subgroups were consistent and in the same direction as those from the main analyses. The association between IFN- $\beta$ and depression was observed only within 2 years of exposure ( $\leq 2$ years); it was not evident with longer exposure ( $>2$ years). Findings were similar for insomnia. Infection risk differed according to the duration of IFN- $\beta$ exposure; while a shorter-term exposure ( $\leq 2$ years) was associated with an increased risk of upper respiratory and other infections, a longer-term exposure ( $>2$ years) was associated with a reduced risk of both bronchitis and upper respiratory infections. Current (but not past) IFN- $\beta$ users had elevated odds of hypertension.

DISCUSSION By conducting a series of nested casecontrol studies in a large cohort of patients with RRMS from BC, we found that exposure to the IFN$\beta$ s was associated with a 1.8-fold increased risk of stroke, a 1.6-fold increased risk of migraine, and a 1.3-fold increase in the risk of depression and hematologic abnormalities. 
Table 3 ORs for IFN- $\beta$ treatment, specified by cumulative duration ( $\leq 2$ and $>2$ years) relative to the unexposed patients with MS

\begin{tabular}{|c|c|c|c|c|c|c|c|c|}
\hline \multirow[b]{2}{*}{$\begin{array}{l}\text { Potential } \\
\text { adverse event }\end{array}$} & \multirow[b]{2}{*}{ No. } & \multirow[b]{2}{*}{$\begin{array}{l}\text { Not exposed } \\
\text { to IFN- } \beta \text {, } \\
\text { n (\%) }\end{array}$} & \multirow[b]{2}{*}{$\begin{array}{l}\leq 2-y \text { IFN- } \beta \\
\text { exposure, } \\
n(\%)^{\mathrm{a}}\end{array}$} & \multirow[b]{2}{*}{$\begin{array}{l}>2-y \text { IFN- } \beta \\
\text { exposuren, } \\
n(\%)^{\mathrm{a}}\end{array}$} & \multirow{2}{*}{$\begin{array}{l}\leq 2-y \text { IFN- } \beta \\
\text { exposure } \\
\mathrm{OR}_{\text {crude }} \\
(95 \% \mathrm{Cl})\end{array}$} & \multirow{2}{*}{$\begin{array}{l}\leq 2-y \text { IFN- } \beta \\
\text { exposure } \\
\text { OR }_{\text {adjusted }} \\
(95 \% \mathrm{Cl})^{b}\end{array}$} & \multirow{2}{*}{$\begin{array}{l}>2-y \text { IFN- } \beta \\
\text { exposure } \\
\\
\text { OR } R_{\text {crude }} \\
(95 \% \mathrm{Cl})\end{array}$} & \multirow{2}{*}{$\begin{array}{l}>2-y \text { IFN- } \beta \\
\text { exposure } \\
\text { OR }_{\text {adjusted }} \\
(95 \% \mathrm{CI})^{\mathrm{b}}\end{array}$} \\
\hline & & & & & & & & \\
\hline \multicolumn{9}{|l|}{ URI } \\
\hline Cases & 1,037 & 792 (76.4) & 151 (14.5) & 94 (9.1) & $1.32(1.09-1.61)$ & $1.32(1.09-1.60)$ & $0.62(0.48-0.78)$ & $0.61(0.48-0.78)$ \\
\hline Controls & 16,173 & 783.5 (75.6) & $115.4(11.1)$ & 138.1 (13.3) & & & & \\
\hline Cases & 863 & 620 (71.8) & 123 (14.3) & 120 (13.9) & $1.42(1.15-1.76)$ & $1.42(1.14-1.75)$ & $0.84(0.67-1.04)$ & $0.84(0.67-1.04)$ \\
\hline Controls & 14,216 & 630.6 (73.1) & 90.6 (10.5) & $141.8(16.4)$ & & & & \\
\hline \multicolumn{9}{|l|}{ Depression } \\
\hline Cases & 842 & 587 (69.7) & 165 (19.6) & 90 (10.7) & $1.86(1.53-2.25)$ & $1.86(1.53-2.25)$ & $0.85(0.66-1.08)$ & $0.85(0.66-1.08)$ \\
\hline Controls & 10,964 & 461.7 (73.3) & 70.5 (11.2) & 97.8 (15.5) & & & & \\
\hline \multicolumn{9}{|l|}{ Hypertension } \\
\hline Cases & 484 & 345 (71.3) & $47(9.7)$ & 92 (19.0) & $1.10(0.80-1.53)$ & $1.15(0.83-1.59)$ & $1.14(0.89-1.48)$ & $1.19(0.92-1.54)$ \\
\hline Controls & 8,232 & 355.5 (73.4) & $44.0(9.1)$ & 84.5 (17.5) & & & & \\
\hline \multicolumn{9}{|l|}{ Dermatitis } \\
\hline Cases & 350 & 256 (73.1) & 44 (12.6) & 50 (14.3) & $1.17(0.83-1.65)$ & $1.17(0.83-1.66)$ & $0.79(0.56-1.11)$ & $0.79(0.57-1.11)$ \\
\hline Controls & 6,246 & 252.9 (72.3) & 37.1 (10.6) & 60.0 (17.1) & & & & \\
\hline \multicolumn{9}{|l|}{ CHD } \\
\hline \multicolumn{9}{|l|}{ Migraine } \\
\hline Cases & 279 & $176(63.1)$ & 42 (15.0) & 61 (21.9) & $1.51(1.05-2.19)$ & $1.51(1.05-2.19)$ & $1.59(1.14-2.22)$ & $1.58(1.13-2.21)$ \\
\hline Controls & 4,969 & $199.2(71.4)$ & 32.5 (11.6) & $47.3(17.0)$ & & & & \\
\hline \multicolumn{9}{|l|}{ Otitis media } \\
\hline Cases & 259 & $172(66.4)$ & 41 (15.8) & 46 (17.8) & $1.36(0.94-1.97)$ & $1.35(0.93-1.96)$ & $1.09(0.76-1.58)$ & $1.08(0.75-1.56)$ \\
\hline Controls & 4,669 & 181.4 (70.1) & 32.8 (12.6) & 44.8 (17.3) & & & & \\
\hline \multicolumn{9}{|l|}{ Asthma } \\
\hline Cases & 229 & $168(73.4)$ & 30 (13.1) & 31 (13.5) & $1.06(0.69-1.62)$ & $1.06(0.69-1.62)$ & $0.70(0.46-1.07)$ & $0.70(0.46-1.07)$ \\
\hline Controls & 4,226 & $161.0(70.3)$ & 27.0 (11.8) & 41.0 (17.9) & & & & \\
\hline \multicolumn{9}{|c|}{ Diabetes mellitus } \\
\hline Cases & 214 & $147(68.7)$ & $18(8.4)$ & 49 (22.9) & $0.97(0.57-1.63)$ & $1.00(0.59-1.69)$ & $1.22(0.85-1.75)$ & $1.24(0.86-1.78)$ \\
\hline Controls & 3,665 & $152.1(71.1)$ & $18.9(8.8)$ & $43.0(20.1)$ & & & & \\
\hline \multicolumn{9}{|l|}{ Pneumonia } \\
\hline Cases & 213 & $146(68.5)$ & 28 (13.2) & 39 (18.3) & $1.36(0.88-2.09)$ & $1.38(0.89-2.13)$ & $0.92(0.63-1.35)$ & $0.94(0.64-1.38)$ \\
\hline Controls & 3,588 & $149.3(70.1)$ & 21.4 (10.0) & 42.3 (19.9) & & & & \\
\hline
\end{tabular}

Continued 


\begin{tabular}{|c|c|c|c|c|c|c|c|c|}
\hline Table 3 & nued & & & & & & & \\
\hline $\begin{array}{l}\text { Potential } \\
\text { adverse event }\end{array}$ & No. & $\begin{array}{l}\text { Not exposed } \\
\text { to IFN- } \beta \text {, } \\
\text { n (\%) }\end{array}$ & $\begin{array}{l}\leq 2-y \text { IFN- } \beta \\
\text { exposure, } \\
n(\%)^{a}\end{array}$ & $\begin{array}{l}>2-y \text { IFN- } \beta \\
\text { exposuren, } \\
n(\%)^{\mathrm{a}}\end{array}$ & $\begin{array}{l}\leq 2-y \text { IFN- } \beta \\
\text { exposure } \\
\\
\text { OR } \\
(95 \% \mathrm{Cl})\end{array}$ & $\begin{array}{l}\leq 2-y \text { IFN- } \beta \\
\text { exposure } \\
\\
\text { OR }_{\text {adjusted }} \\
(95 \% \mathrm{Cl})^{\mathbf{b}}\end{array}$ & $\begin{array}{l}>2-y \text { IFN- } \beta \\
\text { exposure }\end{array}$ & $\begin{array}{l}>2-y \text { IFN- } \beta \\
\text { exposure } \\
\\
\text { OR }_{\text {adjusted }} \\
(95 \% \mathrm{Cl})^{\mathbf{b}}\end{array}$ \\
\hline \multicolumn{9}{|l|}{ Stroke } \\
\hline Controls & 1,688 & 79.1 (74.6) & $9.9(9.4)$ & $17.0(16.0)$ & & & & \\
\hline
\end{tabular}

Abbreviations: $\mathrm{CHD}=$ coronary heart disease; $\mathrm{Cl}=$ confidence interval; IFN- $\beta=$ interferon- $\beta$; MS = multiple sclerosis; OR = odds ratio; URI = upper respiratory infections.

${ }^{a}$ To account for any variation in the number of controls per case between risk sets, all proportions and percentages reported for controls are weighted by the inverse number of controls in each set.

${ }^{\mathrm{b}}$ Adjusted for age (in years) at the cohort entry date; no other covariates were included in the final models because none were associated with case/control status.

Our study is a comprehensive assessment of the potential risks for a broad range of adverse events related to IFN- $\beta$ in the real-world clinical setting. Several of the adverse events that we observed to be associated with IFN- $\beta$ exposure such as migraine, hematologic abnormalities, and depression are included in the known safety profile of the IFN- $\beta$ s. Stroke, on the other hand, is not well recognized as a potential adverse event, being limited to a few case reports. ${ }^{19,20}$ Nonetheless, it is biologically plausible that this event is associated with IFN- $\beta$ because this drug may alter wall competence or enhance the major histocompatibility complex-1 molecule expression of platelets and other cells, ${ }^{21,22}$ resulting in enhanced platelet adhesion to the endothelium. ${ }^{22,23}$ Furthermore, it has been reported that IFN- $\beta$ may exacerbate other underlying autoimmune diseases (such as vasculitis). ${ }^{24}$ Alternatively, when patients experience flulike symptoms caused by the IFN- $\beta s$, treatment with acetaminophen or nonsteroidal anti-inflammatory drugs is recommended. Several studies have suggested an association between nonsteroidal antiinflammatory drugs and the risk of stroke, although the data have been inconclusive. ${ }^{25}$ Another possibility is that the symptoms of MS could mistakenly be attributed to other causes, e.g., stroke, ${ }^{26}$ although to explain our findings, this misclassification would have to occur more frequently in the IFN- $\beta$-treated relative to untreated group, which seems unlikely. Our observation of an elevated risk of migraine extends previous findings; 2 other observational studies showed that patients treated with IFN- $\beta$ experienced headaches/migraine more often than patients treated with glatiramer acetate or natalizumab. ${ }^{27,28}$ However, 4 clinical trials did not report higher rates of headaches in patients with MS treated with IFN- $\beta$ compared to those treated with placebo. ${ }^{29-32}$ This apparent difference with our study findings may be partially explained by the inclusion of headaches as a flu-like symptom, rather than reporting them separately in these clinical trials. ${ }^{27} \mathrm{~A}$ biological rationale for an increased risk of migraine may involve interleukin-10 expression activated by IFN- $\beta$ via the nuclear factor- $\kappa \beta$ pathway ${ }^{33}$; interleukin-10 appears to play a role in the pathogenesis of migraine. ${ }^{34}$ Hypertension can also increase the risk of both migraine $^{35}$ and stroke, and we observed a higher risk for hypertension among current users of IFN- $\beta$, which might point to a common pathway.

In accordance with our finding of an increased risk of hematologic abnormalities, a meta-analysis of placebo-controlled IFN- $\beta$ clinical trials reported a relative risk of 2.7 for leukopenia and 1.2 for lymphopenia. ${ }^{6}$ Increased risk for anemia was reported in one of the pivotal IFN- $\beta$ clinical trials ${ }^{32}$ and is included in all product monographs as a less common event. ${ }^{14-16}$ In our study, individuals with hematologic abnormalities made up a high proportion of anemic patients. The immunomodulatory properties of IFN- $\beta$ may be responsible for initiating leukopenia and lymphopenia $^{23}$ and an increased cytokine release, which may result in the hematopoietic inhibitory responses, explaining the occurrence of anemia. ${ }^{36}$

Several postmarketing studies have investigated the association between IFN- $\beta$ exposure and the risk of incident depression with conflicting results. ${ }^{37}$ One clinical trial of 383 patients with relapsing MS was in line with our findings and showed higher incidence rates of depression in the IFN- $\beta$-treated patients than in the placebo group. ${ }^{32}$ Others, however, have shown no association between the IFN- $\beta$ s and depression. ${ }^{6,37}$ Apparent differences between studies might relate to study designs, measurements for depressive symptoms, treatment of depression, or inclusion of patients with a history of depression. To minimize the last one, we excluded patients with a history of depression in the year before the cohort entry date. However, it remains possible that individuals with 


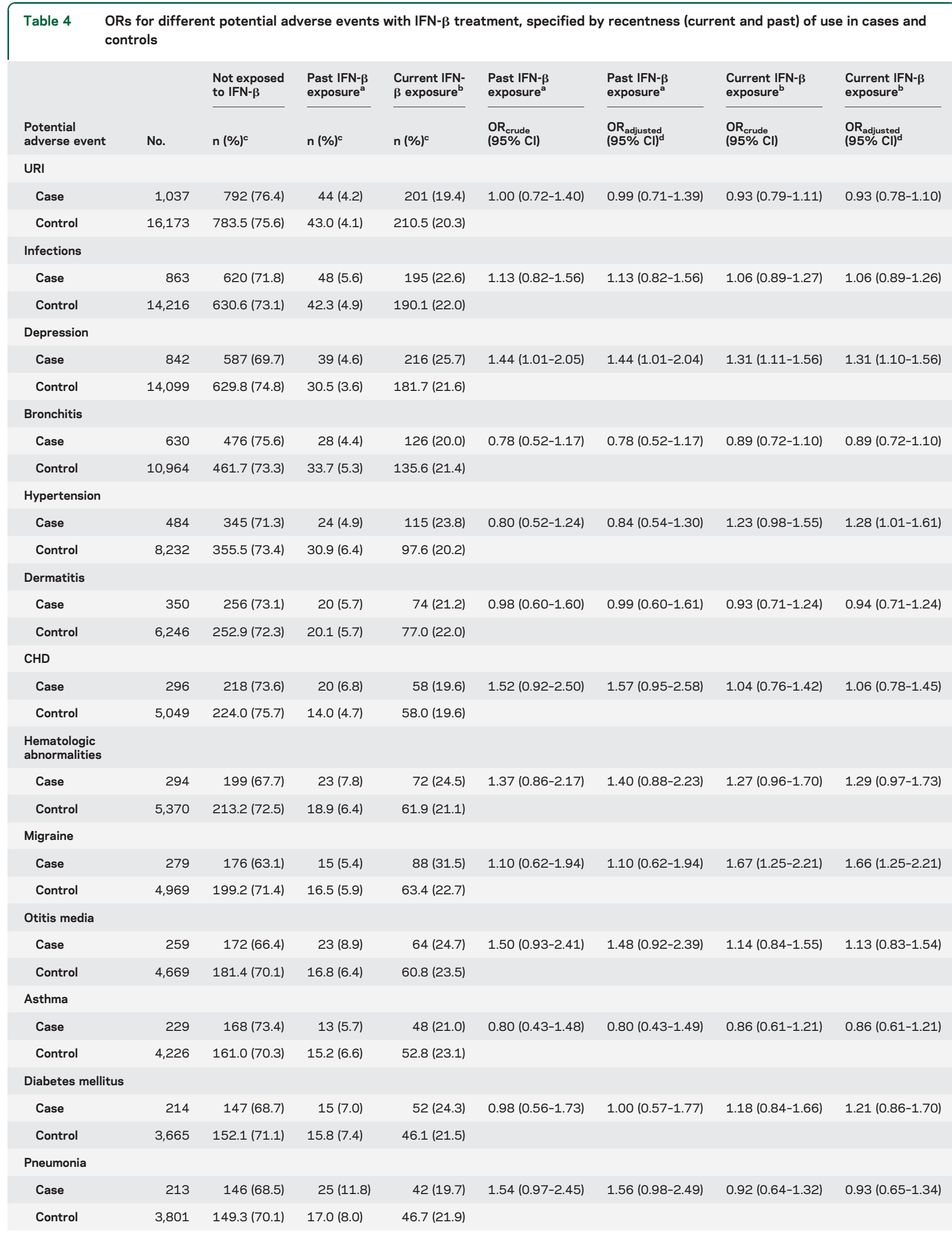


Table 4 Continued

\begin{tabular}{|c|c|c|c|c|c|c|c|c|}
\hline & & $\begin{array}{l}\text { Not exposed } \\
\text { to IFN- } \beta\end{array}$ & $\begin{array}{l}\text { Past IFN- } \beta \\
\text { exposure }^{a}\end{array}$ & $\begin{array}{l}\text { Current IFN- } \\
\beta \text { exposure }\end{array}$ & $\begin{array}{l}\text { Past IFN- } \beta \\
\text { exposure }^{a}\end{array}$ & $\begin{array}{l}\text { Past IFN- } \beta \\
\text { exposure }^{a}\end{array}$ & $\begin{array}{l}\text { Current IFN- } \beta \\
\text { exposure }^{b}\end{array}$ & $\begin{array}{l}\text { Current IFN- } \beta \\
\text { exposure }^{b}\end{array}$ \\
\hline $\begin{array}{l}\text { Potential } \\
\text { adverse event }\end{array}$ & No. & $n(\%)^{c}$ & n (\%) & n (\%) & $\begin{array}{l}\text { OR }_{\text {crude }} \\
(95 \% \mathrm{Cl})\end{array}$ & $\begin{array}{l}\text { OR }_{\text {adjusted }} \\
(95 \% \mathrm{Cl})^{d}\end{array}$ & $\begin{array}{l}\text { OR }_{\text {crude }} \\
\text { (95\% Cl) }\end{array}$ & $\begin{array}{l}\text { OR }_{\text {adjusted }} \\
(95 \% \mathrm{CI})^{d}\end{array}$ \\
\hline \multicolumn{9}{|l|}{ Stroke } \\
\hline Case & 106 & $68(64.1)$ & 13 (12.3) & 25 (23.6) & 2.87 (1.45-5.68) & $2.95(1.48-5.86)$ & $1.51(0.91-2.51)$ & $1.55(0.93-2.58)$ \\
\hline Control & 1,688 & 79.1 (74.6) & $6.1(5.8)$ & 20.8 (19.6) & & & & \\
\hline
\end{tabular}

Abbreviations: $\mathrm{CHD}=$ coronary heart disease; $\mathrm{Cl}=$ confidence interval; IFN- $\beta=$ interferon- $\beta$; OR = odds ratio; URI = upper respiratory infections.

a Past exposure is defined as most recent exposure to an IFN- $\beta$ being $>3$ months before the index date.

${ }^{b}$ Current exposure is defined as exposure to an IFN- $\beta$ in the 3 months preceding the index date.

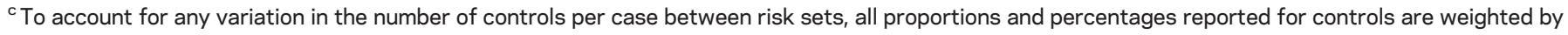
the inverse number of controls in each set.

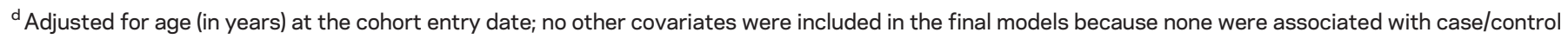
status.

a more remote history of depression could have been included. We found that the increased risk of depression (and insomnia) was evident only in patients with $<2$ years of exposure to IFN- $\beta$.

Our observation of a reduced risk of bronchitis and upper respiratory infections with $>2$ years' exposure to IFN- $\beta$ is in line with previous work from our group (using the same source BCMS cohort) in which cumulative exposure to IFN- $\beta$ was associated with a lower rate of more generally defined respiratory disease-related hospital events. ${ }^{38}$ Although the exact mechanism of action of the IFN- $\beta$ s is not fully understood, they are known to have antiviral effects ${ }^{23}$ and are naturally produced endogenously to facilitate host antimicrobial and immunoregulatory responses to infection. ${ }^{39}$

This study has several strengths. We comprehensively assessed multiple potential adverse events of IFN- $\beta$ treatment using a nested case-control design (the association between exposure to IFN- $\beta$ and the risk of cancer was studied in detail in previous work from our group). ${ }^{40}$ We had access to all hospital, physician, and IFN- $\beta$ exposure data for patients with RRMS, all of whom were diagnosed by neurologists specializing in MS. The proportion of IFN- $\beta$-treated patients during follow-up was typical of that in population-based studies conducted over a similar time period. ${ }^{4,13,40}$ In a universal health care system in which DMDs are covered, potential reasons for not starting a drug might include stable disease, needle phobia, or unwillingness to receive a noncurative treatment. ${ }^{4}$ However, the detection of our outcomes required a patient to access the health system; we were therefore unable to consider self-limiting or selfmanageable episodes such as transient flu-like symptoms. Although we were able to consider the potential influence of socioeconomic status and the presence of previous comorbidities, we were lacking information on other important potential confounders such as health behaviors, treatment adherence, family history, and other lifestyle factors.

Data on IFN- $\beta$ exposure in our study were based primarily on prescription dispensations, which have been shown to be a reliable reflection of drug exposure as determined by home inventory. ${ }^{41} \mathrm{We}$ also had access to detailed start and stop dates for the IFN- $\beta$ s to supplement these data. Nonetheless, we assumed that patients who were on drug or actively filling their prescriptions were adherent. This assumption could have resulted in some misclassification of dose or recentness of IFN- $\beta$ exposure; however, the main findings and their interpretation should not be influenced by this. Furthermore, given the high cost of IFN- $\beta$ s (which includes some copayment on the part of the patient), it is unlikely that patients repeatedly fill these prescriptions and do not use them.

Patients starting IFN- $\beta$ treatment may have visited a health care professional more often or may have been more carefully examined, thereby increasing the likelihood that they would have a clinical condition detected. Conversely, those individuals who were perceived as more likely to develop a clinical condition might have been less likely to start a drug ${ }^{42}$; however, we found no strong indication that comorbidities were differentially distributed between the cases and controls.

The use of only one claim to define a potential adverse event may have resulted in an overestimation of the absolute number of these particular events due to inclusion of some false positives. However, we would not expect our findings regarding the association with IFN- $\beta$ to be influenced by more sensitive detection criteria unless the overestimation of adverse events differed by treatment status.

By presenting an extensive risk profile of the IFN- $\beta$ s, our findings provide new insights into the benefit-risk ratio of the IFN- $\beta$ s in the real-world setting. Our findings complement and extend those 
observed in clinical trials and provide new evidence that IFN- $\beta$ is associated with stroke. Further real-world longitudinal studies to assess the safety profile of other DMDs for MS are needed, as is further follow-up to assess the long-term outcomes of individuals experiencing adverse events. Comparative analyses between DMDs, e.g., IFN- $\beta$, glatiramer acetate, or the newer DMDs, might also prove insightful.

\section{AUTHOR CONTRIBUTIONS}

Dr. Tremlett had full access to all of the data in the study and takes responsibility for the integrity of the data and the accuracy of the data analysis. Study concept and design: de Jong, Kingwell, Shirani, Zhao, Marrie, Petkau, Gustafson, Tremlett. Acquisition of data: Kingwell, Shirani, Evans, Tremlett. Analysis and interpretation of data and statistical analysis: de Jong and Zhu. Interpretation: all authors. Drafting of the manuscript: de Jong, Kingwell, Tremlett. Critical revision of the manuscript: all authors. Obtained funding: Kingwell, Zhao, van der Kop, Gustafson, Petkau, Tremlett. Administrative, technical, or material support: Kingwell, Shirani, Evans, Traboulsee, Tremlett. Study supervision: Tremlett, Kingwell.

\section{ACKNOWLEDGMENT}

The authors are grateful to Tom Duggan, BA, University of British Columbia, Vancouver, Canada, for significant help with data manipulation and conversion, and the Pharmacoepidemiology in MS Research Group for research support. T. Duggan was compensated through study research grants. They also thank Ulrik Hesse, MSc, Statens Serum Institut, Copenhagen, Denmark, for assistance with programming in SAS. They thank P. Rieckmann, MD, Sozialstiftung Bamberg Hospital, Bamberg, Germany, for helpful revisions of the original Canadian Institutes of Health Research grant. They gratefully acknowledge the British Columbia Multiple Sclerosis Clinic neurologists who contributed to the study through patient examination and data collection (see appendix e-3). They also thank the University of British Columbia MS clinic nurses and staff and the University of British Columbia Clinical Trials Group. They thank the BC Ministry of Health, Vital Statistics Agency, and PharmaNet for approval of and support with accessing provincial data, as well as Population Data BC for facilitating approval and use of data. All inferences, opinions, and conclusions drawn in this article are those of the authors and do not reflect the opinions or policies of the data steward(s). Finally, the authors are indebted to all patients with MS who participated in this study.

\section{STUDY FUNDING}

Supported by grant MOP-93646 from the Canadian Institutes of Health Research (principal investigator: Dr. Tremlett) and grant RG 4202-A-2 from the National Multiple Sclerosis Society (principal investigator: Dr. Tremlett). The funding institutions had no role in the design and conduct of the study; in the collection, analysis, and interpretation of the data; or in the preparation, review, or approval of the manuscript.

\section{DISCLOSURE}

H. de Jong was funded by the Michael Smith Foundation for Health Research and the MS Society of Canada (postdoctoral fellowships). E. Kingwell, A. Shirani, and J. Cohen Tervaert report no disclosures relevant to the manuscript. R. Hupperts has received honoraria for lectures or advisory boards and research grants from Biogen, Merck, SanofiAventis, and Novartis. Y. Zhao, F. Zhu, C. Evans, and M. van der Kop report no disclosures relevant to the manuscript. A. Traboulsee has received grant funding from the MS Society of Canada, Canadian Institute for Health Research, Lotte and John Hecht Foundation, Vancouver Hospital Foundation, Roche, and Genzyme; served on clinical trial steering committee for Roche; and received honoraria or travel grants from Teva Canada Innovation, Roche, Merck/EMD Serono, Genzyme, and Chugai Pharmaceuticals. P. Gustafson is supported by the Natural Sciences and Engineering Research Council of Canada. He has received consulting fees from Biogen, J. Petkau holds research funding from the
Natural Sciences and Engineering Research Council of Canada and over the past 3 years has received travel support, honoraria, consulting fees, or fees for service on Data Safety Monitoring Boards or Steering Committees from the Canadian Study Group on Chronic Cerebrospinal Venous Insufficiency, EMD Serono, Myelin Repair Foundation, and Novartis. R. Marrie receives funding from the Canadian Institutes of Health Research, Research Manitoba, MS Society of Canada, Multiple Sclerosis Scientific Foundation, National Multiple Sclerosis Society, Rx\&D Health Research Foundation, Consortium of MS Centers, and Crohn's and Colitis Canada, and has conducted clinical trials funded by Sanofi-Aventis. H. Tremlett is the Canada Research Chair for Neuroepidemiology and Multiple Sclerosis. She currently receives research support from the National Multiple Sclerosis Society, Canadian Institutes of Health Research, MS Society of Canada, and Multiple Sclerosis Scientific Research Foundation. In addition, in the last 5 years, she has received research support from the MS Society of Canada (Don Paty Career Development Award), the Michael Smith Foundation for Health Research (Scholar Award), and the UK MS Trust, as well as speaker honoraria and/or travel expenses to attend conferences from the Consortium of Multiple Sclerosis Centers (2013), National Multiple Sclerosis Society (2012, 2014, 2016), Teva Pharmaceuticals (2011), ECTRIMS (2011, 2012, 2013, 2014, 2015, 2016), UK MS Trust (2011), Chesapeake Health Education Program, US Veterans Affairs (2012), Novartis Canada (2012), Biogen Idec (2014), and American Academy of Neurology (2013, 2014, 2015, 2016). All speaker honoraria are either declined or donated to an MS charity or to an unrestricted grant for use by her research group. Financial support was received from the Canadian Institutes of Health Research (grant MOP-93646; principal investigator: Dr. Tremlett) and from the National Multiple Sclerosis Society (grant RG 4202-A-2; principal investigator: Dr. Tremlett) for the submitted work. Go to Neurology.org for full disclosures.

Received November 16, 2016. Accepted in final form March 21, 2017.

\section{REFERENCES}

1. Browne P, Chandraratna D, Angood C, et al. Atlas of multiple sclerosis 2013: a growing global problem with widespread inequity. Neurology 2014;83:1022-1024.

2. Filippini G, Del Giovane C, Vacchi L, et al. Immunomodulators and immunosuppressants for multiple sclerosis: a network meta-analysis. Cochrane Database Syst Rev 2013;6:CD008933.

3. Rice GRA, Incorvaia B, Munari LM, et al. Interferon in relapsing-remitting multiple sclerosis. Cochrane Database Syst Rev 2001;4:CD002002.

4. Shirani A, Zhao Y, Karim ME, et al. Association between use of interferon beta and progression of disability in patients with relapsing-remitting multiple sclerosis. JAMA 2012;308:247-256.

5. Freedman MS, Selchen D, Arnold DL, et al. Treatment optimization in MS: Canadian MS Working Group updated recommendations. Can J Neurol Sci 2013;40:307-323.

6. Nikfar S, Rahimi R, Abdollahi M. A meta-analysis of the efficacy and tolerability of interferon-beta in multiple sclerosis, overall and by drug and disease type. Clin Ther 2010;32:1871-1888.

7. British Columbia Ministry of Health. PharmaNet [online]. BC Ministry of Health, Data Extract. Data Stewardship Committee; 2010. Available at: http://www.popdata. bc.ca/data. Accessed July 9, 2015.

8. British Columbia Ministry of Health. Medical Services Plan (MSP) Payment Information File [online]. Population Data BC, Data Extract, Ministry of Health; 2010. Available at: http://www.popdata.bc.ca/data. Accessed July 9, 2015.

9. British Columbia Ministry of Health. Discharge Abstract Database (Hospital Separations) [online]. Population Data 
BC, Data Extract, Ministry of Health; 2010. Available at: http://www.popdata.bc.ca/data. Accessed July 9, 2015.

10. Wilkins R, Berthelot JM, Ng E. Trends in mortality by neighbourhood income in urban Canada from 1971 to 1996. Health Rep 2002;13:1-27.

11. British Columbia Ministry of Health. Vital Statistics Deaths [online]. BC Ministry of Health [publisher]. Data Extract. Data Stewardship Committee; 2010. Available at: http://www.popdata.bc.ca/data. Accessed July 9, 2015.

12. British Columbia Ministry of Health. Consolidation File (MSP Registration and Premium Billing) [online]. Population Data BC, Data Extract, Ministry of Health; 2009. Available at: http://www.popdata.bc.ca/data. Accessed July 9, 2015.

13. McKay KA, Tremlett H, Zhu F, Kastrukoff L, Marrie RA, Kingwell E. A population-based study comparing multiple sclerosis clinic users and non-users in British Columbia, Canada. Eur J Neurol 2016;23:1093-1100.

14. EMD Serono, a Division of EMD Inc. Product Monograph Rebif. 2014. Available at: http://www.emdserono. ca. Accessed July 9, 2015.

15. Biogen Inc. Product Monograph Avonex. 2014. Available at: http://www.biogen.ca. Accessed July 9, 2015.

16. Bayer Inc. Product Monograph Betaseron. 2014. Available at: http://www.bayer.ca. Accessed July 9, 2015.

17. Essebag V, Platt RW, Abrahamowicz M, Pilote L. Comparison of nested case-control and survival analysis methodologies for analysis of time-dependent exposure. BMC Med Res Methodol 2005;5:5.

18. Mickey RM, Greenland S. The impact of confounder selection criteria on effect estimation. Am J Epidemiol 1989;129:125-137.

19. Tremlett HL, Oger J. Ten years of adverse drug reaction reports for the multiple sclerosis immunomodulatory therapies: a Canadian perspective. Mult Scler 2008;14:94-105.

20. Bosche B, Dohmen C, Impekoven P, Pilote L. Stroke after initiation of interferon-beta treatment for relapsingremitting disseminated white matter disease. Acta Neurol Scand 2006;113:433-436.

21. Atta MS, Irving WL, Powell RJ, Todd I. Enhanced expression of MHC class I molecules on cultured human thyroid follicular cells infected with reovirus through induction of type 1 interferons. Clin Exp Immunol 1995;101:121-126.

22. Moore PM, Richardson B. Neurology of the vasculitides and connective tissue diseases. J Neurol Neurosurg Psychiatry 1998;65:10-22.

23. Dhib-Jalbut $S$, Marks S. Interferon-beta mechanism of action in multiple sclerosis. Neurology 2010;74:S17-S24.

24. Watts RA. Musculoskeletal and systemic reactions to biological therapeutic agents. Curr Opin Rheumatol 2000;12: 49-52.

25. Park K, Bavry AA. Risk of stroke associated with nonsteroidal anti-inflammatory drugs. Vasc Health Risk Manag 2014;10:25-32.

26. Libman RB, Wirkowski D, Alvir J, et al. Conditions that mimic stroke in the emergency department. Arch Neurol 1995;52:1119-1122.

27. Pollmann W, Erasmus LP, Feneberg W, Then Bergh F, Straube A. Interferon beta but not glatiramer acetate therapy aggravates headaches in MS. Neurology 2002; 59:636-639.

28. Villani V, Prosperini L, De Giglio L, Pozzilli C, Salvetti $\mathrm{M}$, Sette G. The impact of interferon beta and natalizumab on comorbid migraine in multiple sclerosis. Headache 2012;52:1130-1135.

29. PRISMS (Prevention of Relapses and Disability by Interferon beta-1a Subcutaneously in Multiple Sclerosis) Study Group. Randomised double-blind placebo-controlled study of interferon beta-1a in relapsing/remitting multiple sclerosis. Lancet 1998;352:1498-1504.

30. IFNB Multiple Sclerosis Study Group. Interferon beta-1b is effective in relapsing-remitting multiple sclerosis, I: clinical results of a multicenter, randomized, double-blind, placebo-controlled trial. Neurology 1993;43:655-661.

31. IFNB Multiple Sclerosis Study Group and the University of British Columbia MS/MRI Analysis Group. Interferon beta- $1 \mathrm{~b}$ in the treatment of multiple sclerosis: final outcome of the randomized controlled trial. Neurology 1995; 45:1277-1285.

32. Jacobs LD, Cookfair DL, Rudick RA, et al. Intramuscular interferon beta-1a for disease progression in relapsing multiple sclerosis: the Multiple Sclerosis Collaborative Research Group (MSCRG). Ann Neurol 1996;39:285-294.

33. Yang CH, Murti A, Pfeffer SR, Basu L, Kim JG, Pfeffer LM. IFNalpha/beta promotes cell survival by activating NF-kappa B. Proc Natl Acad Sci USA 2000;97:1363113636.

34. Munno I, Marinaro M, Bassi A, Cassiano MA, Causarano $\mathrm{V}$, Centonze V. Immunological aspects in migraine: increase of IL-10 plasma levels during attack. Headache 2001;41:764-767.

35. Scher AI, Terwindt GM, Picavet HSJ, Verschuren WM, Ferrari MD, Launer LJ. Cardiovascular risk factors and migraine: the GEM population-based study. Neurology 2005;64:614-620.

36. Robb L. Cytokine receptors and hematopoietic differentiation. Oncogene 2007;26:6715-6723.

37. Goeb JL, Even C, Nicolas G, Gohier B, Dubas F, Garre JB. Psychiatric side effects of interferon-beta in multiple sclerosis. Eur Psychiatry 2006;21:186-193.

38. Evans C, Zhu F, Kingwell E, et al. Association between beta-interferon exposure and hospital events in multiple sclerosis. Pharmacoepidemiol Drug Saf 2014;23:12131222.

39. Randall RE, Goodbourn S. Interferons and viruses: an interplay between induction, signalling, antiviral responses and virus countermeasures. J Gen Virol 2008;89:1-47.

40. Kingwell E, Evans C, Zhu F, Oger J, Hashimoto S, Tremlett H. Assessment of cancer risk with $\beta$-interferon treatment for multiple sclerosis. J Neurol Neurosurg Psychiatry 2014;85:1096-1102.

41. Lau HS, de Boer A, Beuning KS, Porsius A. Validation of pharmacy records in drug exposure assessment. J Clin Epidemiol 1997;50:619-625.

42. Zhang $\mathrm{T}$, Tremlett $\mathrm{H}$, Leung $\mathrm{S}$, et al. Examining the effects of comorbidities on disease-modifying therapy use in multiple sclerosis. Neurology 2016;86:1287-1295. 


\section{Neurology}

Evaluating the safety of $\beta$-interferons in MS: A series of nested case-control studies Hilda J.I. de Jong, Elaine Kingwell, Afsaneh Shirani, et al. Neurology 2017;88;2310-2320 Published Online before print May 12, 2017

DOI 10.1212/WNL.0000000000004037

This information is current as of May 12, 2017

Neurology ${ }^{\circledR}$ is the official journal of the American Academy of Neurology. Published continuously since 1951, it is now a weekly with 48 issues per year. Copyright Copyright $@ 2017$ The Author(s). Published by Wolters Kluwer Health, Inc. on behalf of the American Academy of Neurology.. All rights reserved. Print ISSN: 0028-3878. Online ISSN: 1526-632X.

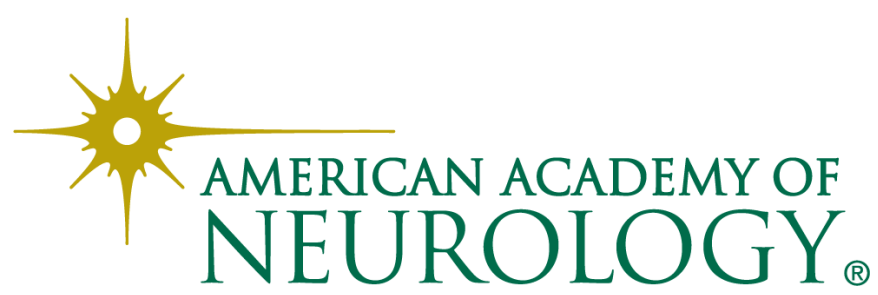




\section{Updated Information \& Services}

\section{Supplementary Material}

\section{References}

Citations

Subspecialty Collections

\section{Permissions \& Licensing}

\section{Reprints}

including high resolution figures, can be found at: http://n.neurology.org/content/88/24/2310.full

Supplementary material can be found at: http://n.neurology.org/content/suppl/2017/05/12/WNL.0000000000004 037.DC1

http://n.neurology.org/content/suppl/2017/05/12/WNL.0000000000004 037.DC2

http://n.neurology.org/content/suppl/2017/06/20/WNL.0000000000004 037.DC3

This article cites 34 articles, 10 of which you can access for free at: http://n.neurology.org/content/88/24/2310.full\#ref-list-1

This article has been cited by 3 HighWire-hosted articles: http://n.neurology.org/content/88/24/2310.full\#\#otherarticles

This article, along with others on similar topics, appears in the following collection(s):

\section{All epidemiology}

http://n.neurology.org/cgi/collection/all_epidemiology

Case control studies

http://n.neurology.org/cgi/collection/case_control_studies Multiple sclerosis

http://n.neurology.org/cgi/collection/multiple_sclerosis

\section{Patient safety}

http://n.neurology.org/cgi/collection/patient_safety

Information about reproducing this article in parts (figures,tables) or in its entirety can be found online at:

http://www.neurology.org/about/about_the_journal\#permissions

Information about ordering reprints can be found online:

http://n.neurology.org/subscribers/advertise

Neurology ${ }^{\circledR}$ is the official journal of the American Academy of Neurology. Published continuously since 1951, it is now a weekly with 48 issues per year. Copyright Copyright ( 2017 The Author(s). Published by Wolters Kluwer Health, Inc. on behalf of the American Academy of Neurology.. All rights reserved. Print ISSN: 0028-3878. Online ISSN: 1526-632X.

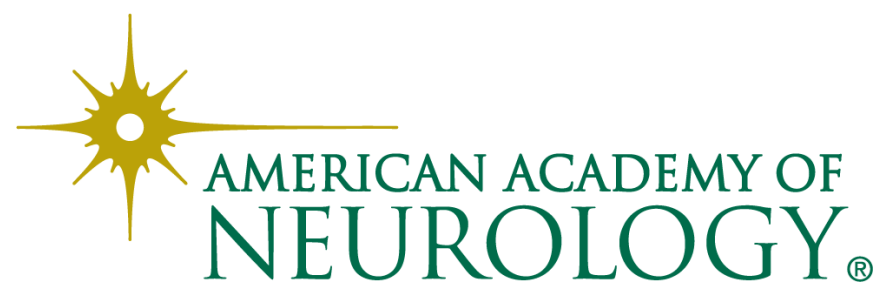

